\title{
Lung infection rates in two sympatric Tropiduridae lizard species by pentastomids and nematodes in northeastern Brazil
}

\author{
Almeida, WO. ${ }^{\mathrm{a}}$, Ribeiro, SC. ${ }^{\mathrm{a}}$, Santana, GG. ${ }^{\mathrm{b}}$, Vieira, WLS. ${ }^{\mathrm{b}}$, Anjos, LA. ${ }^{\mathrm{c}}$ and Sales, DL. ${ }^{\mathrm{a}}$ \\ a'Departamento de Química Biológica, Centro de Ciências Biológicas e da Saúde - CCBS, Campus do Pimenta, \\ Universidade Regional do Cariri - URCA, Rua Cel. Antônio Luiz, 1161, CEP 63105-100, Crato, CE, Brazil \\ bPrograma de Pós-Graduação em Ciências Biológicas (Zoologia), Laboratório/Coleção de Herpetologia, \\ Departamento de Sistemática e Ecologia, Centro de Ciências Exatas e da Natureza - CCEN, Campus I, \\ Universidade Federal da Paraíba - UFPB, Cidade Universitária, CEP 58059-900, João Pessoa, PB, Brazil
}

'Laboratório de Parasitologia de Animais Silvestres - LAPAS, Departamento de Parasitologia, Instituto de Biociências, Universidade Estadual Paulista - UNESP, Distrito de Rubião Junior, s/n, CEP 18618-000, Botucatu, SP, Brazil

*e-mail: waltecio@gmail.com

Received April 17, 2008 - Accepted May 2, 2008 - Distributed August 31, 2009

\begin{abstract}
We present data on pulmonary infection rates by parasites in the lizards Tropidurus hispidus Spix, 1825 and T. semitaeniatus (Spix, 1825) living sympatrically in the Chapada do Araripe mountain Range, northeastern Brazil. We found no parasite pulmonary infection in T. semitaeniatus. However, two pulmonary parasite species were found in the T. hispidus hosts, the pentastomid Raillietiella mottae Almeida, Freire and Lopes, 2008 and the nematode Rhabdias sp. Overall prevalence was 5\%. Prevalence of $R$. mottae was $2.5 \%$ and corresponded to only one parasite on each infected host. Prevalence of Rhabdias sp. was $2.5 \%$ and the range of infection was 1-2 parasites per host. This represents the first record of Rhabdias infecting lizards of the family Tropiduridae in the Neotropical region. Furthermore, we present a comparison of parameters of infection by pulmonary parasites including some recent studies in Brazil.
\end{abstract}

Keywords: Raillietiella, Rhabdias, Pentastomida, neotropical region.

\section{Taxas de infecção pulmonar em duas espécies simpátricas de lagartos Tropiduridae por pentastomídeos e nematódeos na região Nordeste do Brasil}

\begin{abstract}
Resumo
Apresentamos dados sobre taxas de infecção pulmonar por parasitas nos lagartos Tropidurus hispidus e T. semitaeniatus que vivem simpatricamente na encosta da Chapada do Araripe, situada na região Nordeste do Brasil. Não encontramos infecção parasitária nos pulmões dos espécimes de T. semitaeniatus. Entretanto, foram encontradas duas espécies de parasitas nos hospedeiros T. hispidus, os pentastomídeos Raillietiella mottae e os nematódeos Rhabdias sp. A prevalência geral de infecção foi de $5 \%$. A prevalência de infecção de $R$. mottae foi de $2,5 \%$ correspondendo a apenas um parasita por hospedeiro. A prevalência de infecção de Rhabdias sp. foi de $2,5 \%$ e a amplitude de infecção de 1-2 parasitas por hospedeiros. Esses resultados compreendem o primeiro registro de Rhabdias infectando lagartos da família Tropiduridae em toda a região Neotropical. Apresentamos também uma comparação com os parâmetros de infecção pulmonar por parasitas incluindo os estudos mais recentes no Brasil.
\end{abstract}

Palavras-chave: Raillietiella, Rhabdias, Pentastomida, região neotropical.

\section{Introduction}

The parasite-host relationship is an important parameter in the study of animal communities (Rocha et al., 2000), and the knowledge of parasite's biology and the regulatory factors of host-parasite interactions are fundamental to conservation and management of hosts in situ as well as in zoos or in captivity (Klingenberg, 1993; Marcogliese, 2004). Although most of the studies of parasitism in vertebrates are mainly concerned with economic questions (Cunha-Barros et al., 2003), ecological studies focusing interactions between parasites and their lizard hosts have been relatively well documented in Brazil over the last two decades (Ribas et al., 1995, 1998; Rocha, 1995; Vrcibradic et al., 1999; 2000; 2002a, b, 2007; Bursey et al., 2003; Rocha and Vrcibradic, 2003; Rocha et al., 2003; Dias et al., 2005; Anjos et al., 2005, 2007; 2008; Goldberg et al., 2006; Almeida et al., 2008a, 2008b, 2009).

Pentastomids and the nematode Rhabdias Stiles and Hassall, 1905 are common parasites of the respiratory tracts of vertebrates (Riley, 1986; Almeida and Christoffersen, 2002; Bursey et al., 2003). Pentastomids have been relatively poorly studied in the Neotropical region, despite 
its importance as a parasite of vertebrate (Almeida and Christoffersen, 2002). However, the recent reports of parasite occurrence, the new species descriptions, and the information concerning new host records have added knowledge on pentastomid-lizard interactions (Vrcibradic et al., 2002a; Dias et al., 2005; Anjos et al., 2007; 2008; Almeida et al., 2008a; 2008b; 2009). On the other hand, reports concerning lung infections by Rhabdias have been relatively less frequent - and only an infection in the lizard Enyalius bilineatus (Duméril and Bibron, 1837) (Leiosaurinae) from an area of Atlantic Rainforest in Espírito Santo state, southeastern Brazil (Vrcibradic et al., 2007) and an infection of Norops fuscoauratus (d'Orbingy, 1837) (Polychrotidae) in northern Brazil (Goldberg et al., 2006) have been previously reported.

In the present study we provide data on pulmonary infections caused by pentastomids and nematodes species associated with two sympatric species of lizard hosts, Tropidurus hispidus Spix, 1825 and T. semitaeniatus (Spix, 1825), from northeastern Brazil. Further, our data were contrasted with the recent literature on pulmonary infection of lizards.

\section{Materials and Methods}

Field work was carried out on the lower slopes of the Chapada do Araripe Mountains (07 $16^{\prime} \mathrm{S}$ and $39^{\circ} 26^{\prime} \mathrm{W}$ ) within the limits of the environmental protection area (EPA) of Chapada do Araripe in the municipality of Crato, Ceará state, Brazil. The vegetation of the region comprises a mosaic of palm tree, montane forest, and secondary forests. The area has been subjected to anthropogenic alteration due to land occupation for agricultural purposes, the harvesting of natural products, and the speculation in property. The regional climate is warm, semi-arid tropical, with the mean annual temperatures ranging between 24 and $26{ }^{\circ} \mathrm{C}$. The rainy season extends from January to May and the annual mean rainfall is 1,100 mm (IPECE, 2005).

Lizards were captured using rubber slings, nooses, or by hand. Immediately after capture each lizard was transferred to a plastic sack containing cotton embedded in ether, in order to anaesthetize and euthanize them. The snout-vent length (SVL) of the lizards was measured with a caliper (to the nearest $0.05 \mathrm{~mm}$ ). Lizards were fixed in $10 \%$ formalin and storage in $70 \%$ alcohol.

The lungs of the lizards were removed and checked under a stereo-microscope for the presence of parasites. The parasites found were removed and preserved in $70 \%$ alcohol. For species identification, the pentastomid specimens were mounted on permanent slides in Hoyer medium, and the nematodes were fixed in situ, cleared in glycerol on a glass slide, and subsequently examined under a light microscope.

Pentastomids were identified based on the dimensions of their hooks and the copulatory spicules of males (Ali et al., 1984; 1985; Almeida et al., 2008a). The nematodes were identified to the level of genus Rhabdias, accord- ing to Vicente et al. (1993). Voucher specimens of lizard hosts were deposited in the Herpetological Collection of the Zoology Laboratory of the Regional University of Cariri (collection numbers LZ-URCA 200-286, 300-311). All parasite specimens were deposited in the Zoology Laboratory of the Regional University of Cariri (collection numbers LZ-URCA 401-405).

\section{Results}

A total of 99 lizards were captured. The 80 specimens of T. hispidus ranged in SVL from 41.0 to $113.0 \mathrm{~mm}($ mean $=80.8 \pm 18.5 \mathrm{~mm})$ and the 19 specimens of $T$. semitaeniatus ranged from 31.0 to $77.0 \mathrm{~mm}$ $($ mean $=55.9 \pm 15.7 \mathrm{~mm})$.

Analysis of T. hispidus revealed that four individuals were infected by pulmonary parasites (overall prevalence was 5\%). Two adult males (SVL $=95 \mathrm{~mm}$ and $110 \mathrm{~mm}$ ) were infected by the pentastomid Raillietiella mottae Almeida, Freire and Lopes, 2008 (pentastomid prevalence was $2.5 \%$; intensity of infection was one parasite in each lizard infected) while two other specimens (an adult male, SVL $=78 \mathrm{~mm}$, and an adult female, $\mathrm{SVL}=85 \mathrm{~mm}$ ) were infected by an unidentified species of nematode Rhabdias sp. (nematode prevalence was $2.5 \%$, range of infection was 1-2). No juvenile host was infected. Due to the low overall prevalence, ontogenetic and sexual differences could not be estimated.

There were no pulmonary parasites in the specimens of $T$. semitaeniatus analyzed.

\section{Discussion}

Interactions between the parasite Raillietiella mottae and the lizard host $T$. semitaeniatus have been studied in the Caatinga region, northeastern Brazil (Almeida et al., 2008). The absence of these parasites in the lungs of $T$. semitaeniatus in the present study may simply be related to the low numbers of that host sampled. These two lizard species share similar feeding resources and microhabitats (Vanzolini et al., 1980; Vitt, 1995), which would otherwise favor the acquisition of a similar parasite fauna (see Almeida et al., 2008b).

Raillietiella mottae does not attain core species status (i.e., prevalence $>50 \%$; Aho, 1990) in the regions of Caatinga studied. In the present study its prevalence of $2.5 \%$ is inferior to its reported infection levels in Hemidactylus mabouia (Moreau de Jonnès, 1818) (2.7\%), Phyllopesus pollicaris (Spix, 1825) (16.6\%), P. periosus Rodrigues, 1986 (66.7\%), T. hispidus (11.1\%) and T. semitaeniatus (13.3\%) in other areas from northeastern Brazilian (Almeida et al., 2008a; 2008b; Anjos et al., 2007; 2008) (Table 1). Nevertheless, the prevalence of Raillietiella spp. in lizards from Caatinga region (present study; Anjos et al., 2007; 2008; Almeida et al., 2008a; 2008b) were greater than that recorded for some lizard species in Restinga habitats (coastal sandy dune habitats) (Table 1) for the Scincidae host Mabuya agilis Raddi, 


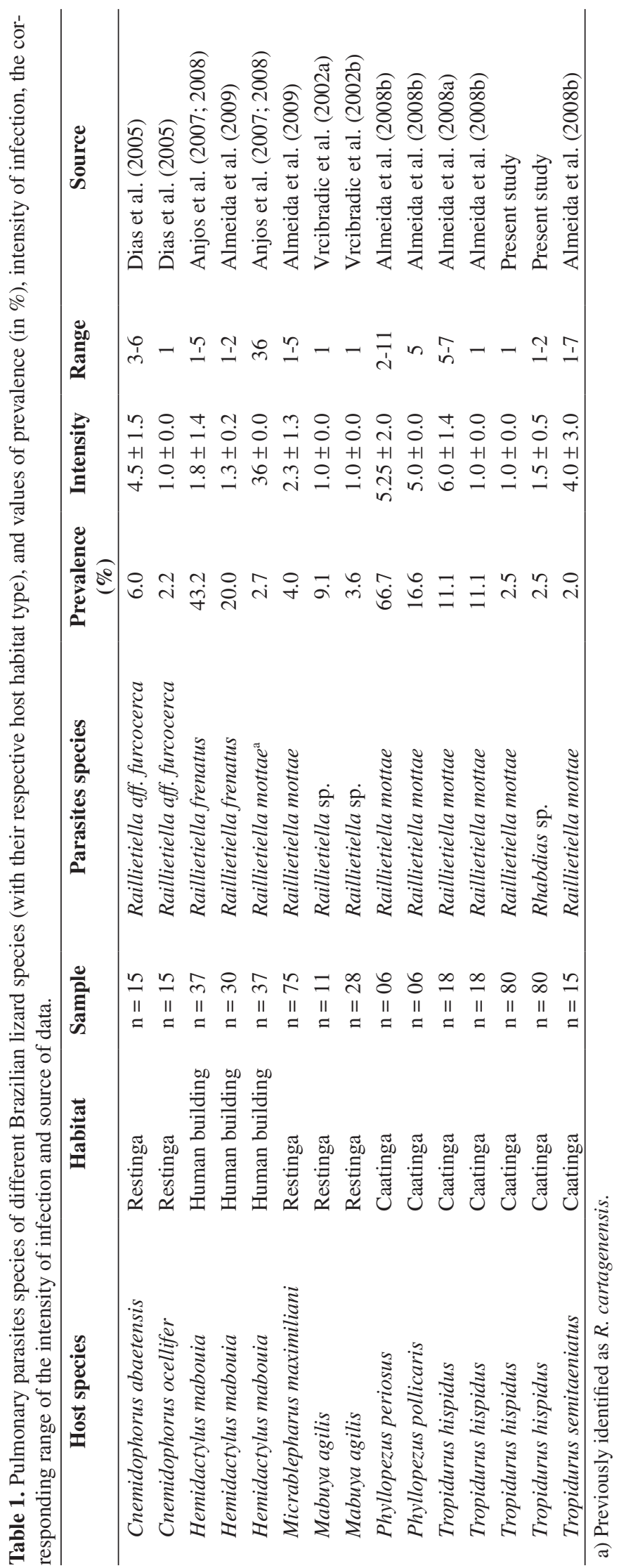


1823 (3.6-9.0\%, Vrcibradic et al., 2002b); the Teiidae hosts Cnemidophorus ocellifer (Spix, 1825) (2.5\%, Dias et al., 2005) and C. abaetensis Dias, Rocha and Vrcibradic, 2002 (6.0\%, Dias et al., 2005), and the Gymnophtalmidae Micrablepharus maximiliani (Reinhardt and Luetken, 1862) (4.0\%, Almeida et al., 2009).

As we found in the present study, the mean intensity of infection by pentastomids is in general low in theirhost species according to available literature: $C$. abaetensis (4.5 \pm 0.0, Dias et al., 2005), C. ocellifer $(1.0 \pm 0.0$, Dias et al., 2005), M. agilis (1.0 \pm 0.0 , Vrcibradic et al., 2002a), M. maximiliani (2.3 \pm 1.3 , Almeida et al., 2009) in the restinga habitat; $P$. periosus $(5.25 \pm 2.0$, Almeida et al., 2008b), P. pollicaris (5.0, Almeida et al., 2008b), T. hispidus (1.0 \pm 0.0, Almeida et al., 2008a; 2008b), T. semitaeniatus ( $4.0 \pm 3.0$, Almeida et al., 2008b) in the caatinga and $H$. mabouia $(1.8 \pm 1.4$ and $1.33 \pm 0.2$, Anjos et al., 2007; 2008; Almeida et al., 2009) in human habitations (Table 1).

Nematode parasites of the genus Rhabdias have been little studied in Brazil and could not be identified to the species level in this study. Rhabdias has been reported in the Neotropical region in host species of the genera Anolis (Polychrotidae) (Bundy et al., 1987; Dobson et al., 1992; Bursey et al.; 2003; 2004), Enyalius (Leisosauridae) (Vrcibradic et al., 2007) and in Tropidurus (Tropiduridade) in the present study. Rhabdias is a parasite less frequently found in the lungs of lizards (Bursey et al., 2003). However, it is important to stress that due to the low numbers of studies on endoparasites of lizards in South America (Vrcibradic, 2007), many groups of lizard from so many distinct environments still need to be more fully investigated. The current knowledge of infections by Rhabdias in lizards in Brazil is based on two studies that reported the presence of parasites in the lizards Norops fuscoauratus (Goldberg et al., 2006) and in Enyalius bilineatus (Vrcibradic et al., 2007). The former species presented prevalence values of $1.8 \%$ and mean intensity of infection of $2.0 \pm 0.0$ (Goldberg et al., 2006), values somewhat similar to those found to T. hispidus (2.5\%; range of infection was 1-2), in the present study. According to Vrcibradic et al. (2007), E. bilineatus showed the greatest prevalence (33.3\%) and mean intensity of infection $(2.0 \pm 1.1)$.

In the present study, T. hispidus constitutes a new host for Rhabdias sp., being also the first record of this parasite species in a Tropiduridae lizard species in the Neotropical region.

The presence of the pentastomid $R$. mottae and the nematode Rhabdias sp. both infecting the lungs of the same host species, and with similar infection rates, suggests that these parasites can share simultaneously the same microhabitat in the host body. The low prevalence of R. mottae and Rhabdias sp. in the host species analyzed suggests that these two parasites do not represent core species in that area, and that their occurrence may be an occasional or accidental occurrence. With the development of further studies involving new hosts, we can understand the patterns of infection and the aspects of relationship between the parasites and lizards in the region of Cariri, northeastern Brazil.

Acknowledgements - The authors would like to thank the Fundação Cearense de Apoio ao Desenvolvimento Científico e Tecnológico - FUNCAP (process number BPI-0112-2.05/08) for the study grant awarded to the first author; the Fundação Coordenação de Aperfeiçoamento de Pessoal de Nível Superior (CAPES) for the scholarship to GG Santana and LA Anjos; IBAMA for the collecting permit (007/ 2007 - CGFAP/ IBAMA 02007.001009/2004); Geraldo Saraiva Ribeiro and his family who kindly let us use their home as a research station during the fieldwork; Francisco Nascimento Pereira Júnior and Morgana Maria de Sousa Delfino for their help in the field; and Roy Funch (UEFS) for reviewing the manuscript. The experiments comply with the current laws of the country in which they were performed.

\section{References}

AHO, JM., 1990. Helminthes communities of amphibians and reptiles: comparative approaches to understanding patterns and process. In ESCH, GW., BUSH, AO. and AHO, JM. (Eds.). Parasite communities: patterns and process. London; New York: Chapman and Hall. p. 157-190.

ALI, JH., RILEY, J. and SELF, JT., 1984. A revision of the taxonomy of pentastomid parasites (genus Raillietiella Sambon, 1910) from American snakes and amphisbaenians. Systematic Parasitology, vol. 6, no. 2, p. 87-97.

1985. A review of the taxonomy and systematics of the pentastomids genus Raillietiella Sambon, 1910 with a description of a new species. Systematic Parasitology, vol. 7, no. 2, p. 111-123.

ALMEIDA, WO. and CHRISTOFFERSEN, ML., 2002. Pentastomida. In MORRONE, J. and LLORENTEBOUSQUETS, J. (Eds.). Biodiversidad, taxonomía y biogeografía de artrópodos de México: hacia una síntesis de su conocimiento. Ciudad de México: Universidad Nacional Autónoma de México. p. 187-202.

ALMEIDA, WO., VASCONCELLOS, A., FREIRE, EMX. and LOPES, SG., 2008a. A new species of Pentastomida infecting Tropidurus hispidus (Squamata: Tropiduridae) from caatinga in Northeastern Brazil. Revista Brasileira de Biologia = Brazilian Journal of Biology, vol. 68, no. 1, p. 631-637.

ALMEIDA, WO., SANTANA, GG., VIERIA, WLS., WANDERLEY, IC., FREIRE, EMX. and VASCONCELLOS, A., 2008b. Pentastomid, Raillietiella mottae Almeida, Freire and Lopes, 2008, infecting lizards in an area of caatinga, northeast, Brazil. Revista Brasileira de Biologia = Brazilian Journal of Biology, vol. 68, no. 2, p. 203-207.

ALMEIDA, WO., SANTANA, GG., VIERIA, WLS. and WANDERLEY, IC., 2008c. Infection rates of pentastomids on lizards in urban habitats from Brazilian Northeast. Revista Brasileira de Biologia = Brazilian Journal of Biology, vol. 68, no. 4 , p. 885-888.

ALMEIDA, WO., SANTANA, GG., VIERIA, WLS., WANDERLEY, IC. and RIBEIRO, S., 2009. Rates of pulmonary infection by pentastomids in two lizard species from a restinga habitat in northeastern Brazil. Revista Brasileira de Biologia = Brazilian Journal of Biology, vol. 69, no. 1, p. 631-637. 
ANJOS, LA., ROCHA, CFD., VRCIBRADIC, D. and VICENTE, JJ., 2005. Helminths of exotic lizard Hemidactylus mabouia from a rock outcrop area in southeastern Brazil. Journal of Helminthology, vol. 79, no. 4, p. 307-313.

ANJOS, LA., ALMEIDA, WO., VASCONCELLOS, A., FREIRE, EMX. and ROCHA, CFD., 2007. The alien and native pentastomids fauna of an exotic lizard population from Brazilian Northeast. Parasitology Research, vol. 101, no. 3, p. 627-628.

ANJOS, LA., ALMEIDA, WO., VASCONCELLOS, A., FREIRE, EMX. and ROCHA, CFD., 2008. Pentastomids infecting an invader lizard, Hemidactylus mabouia (Gekkonidae) in northeastern Brazil. Revista Brasileira de Biologia $=$ Brazilian Journal of Biology, vol. 68, no. 3, p. 611-615.

BUNDY, DAP., VOGEL, P. and HARRIS, EA., 1987. Helminth parasites of Jamaican Anoles (Reptilia: Iguanidae): on a comparison of the helminth fauna of 6 anoles species. Journal of Helminthology, vol. 61, no. 1, p. 77-83.

BURSEY, CR., GOLDBERG, SR. and TELFORD, SR., 2003. Rhabdias anolis $\mathrm{n}$. sp. (Nematoda: Rhabdiasidae) from a lizard, Anolis frenatus (Sáuria: Polychrotidae), from Panama. Journal of Parasitology, vol. 89, no. 1, p. 113-117.

BURSEY, CR., GOLDBERG, SR. and MILLER CL., 2004. Two new species of Falcaustra and comments on helminths from the lizard Norops tropidolepis (Sauria: Polychrotidae) from Costa Rica. Journal of Parasitology, vol. 90, no. 3, p. 598-603.

CUNHA-BARROS, M., VAN SLUYS, M., VRCIBRADIC, D., GALDINO, CAB., HATANO, FH. and ROCHA, CFD., 2003. Patterns of infestation by chigger mites in four diurnal lizard species from a restinga habitat (Jurubatiba) of Southeastern Brazil. Revista Brasileira de Biologia = Brazilian Journal of Biology, vol. 63, no. 3, p. 393-399.

DIAS, EJR., VRCIBRADIC, D. and ROCHA CFD., 2005. Endoparasites infecting two species of whiptail lizards (Cnemidophorus abaetensis and $C$ ocellifer; Teiidae) in a restinga habitat of northeastern Brazil. Herpetological Journal, vol. 15 , no. 2 , p. 133-137.

DOBSON, AP., PACALA, SV., ROUGHGARDEN, JD., CARPER, ER. and HARRIS, EA., 1992. The parasites of Anolis lizards in the northern Lesser Antilles I. Patterns of distribuition and abundance. Oecologia, vol. 91, no. 1, p. 110-117.

GOLDBERG, SR., BURSEY, CR. and VITT, LJ., 2006. Helminths of the Brown-eared anole, Norops fuscoauratus (Squamata, Polychrotidae), from Brazil and Ecuador, South America. Phyllomedusa, vol. 5, no. 1, p. 83-86.

Instituto de Pesquisa e Estatística Econômica do Ceará - IPECE, 2005. Perfil básico municipal: crato. Fortaleza: Governo do Estado do Ceará, Secretaria do Planejamento e Coordenação.

KLINGENBERG, RJ., 1993. Understanding reptile parasites. Irvine: Advanced Vivarium Systems. 83p.

MARCOGLIESE, DJ., 2004. Parasites: small players with crucial roles in the ecological theater. Ecohealth, vol. 1, no. 2, p. $151-164$

RIBAS, SC., ROCHA, CFD., TEIXEIRA-FILHO, PF. and VICENTE, JJ., 1995. Helminths (Nematoda) of the lizard Cnemidophorus ocellifer (Sauria: Teiidae): assessing the effect of rainfall, body size and sex in the nematode infection rates. Ciência e Cultura, vol. 47, no. 1-2, p. 88-91.
RIBAS, SC., ROCHA, CFD., TEIXEIRA-FILHO, PF. and VICENTE, JJ., 1998. Nematode infection in two sympatric lizards (Tropidurus torquatus and Ameiva ameiva) with different foraging tactics. Amphibia-Reptilia, vol. 19, no. 3, p. 323-330.

RILEY, J., 1986. The biology of pentastomids. Advances in Parasitology, vol. 25, p. 45-128.

ROCHA, CFD., 1995. Nematode parasites of the Brazilian sand lizard. Liolaemus lutzae. Amphibia-Reptilia, vol. 16, no. 4, p. $412-415$.

ROCHA, CFD. and VRCIBRADIC, D., 2003. Nematode assemblages of some of some insular and continental lizard hosts of the genus Mabuya Fitzinger (Reptilia, Scincidae) along the eastern Brazilian coast. Revista Brasileira de Zoologia, vol. 20, no. 4, p. 755-759.

ROCHA, CFD., VRCIBRADIC, D. and ARAÚJO, AFB., 2000. Ecofisiologia de répteis de restingas Brasileiras. In ESTEVES, FA. and LACERDA, LD. (Eds.). Ecologia de restingas e lagoas costeiras. Macaé: NUPEM; UFRJ. p. 117-149.

ROCHA, CFD., VRCIBRADIC, D., VICENTE, JJ. and CUNHA-BARROS, M., 2003. Helminths infecting Mabuya dorsivittata (Lacertilia, Scincidae) from a high-altitude habitat in Itatiaia National Park, Rio de Janeiro State, southeastern Brazil. Revista Brasileira de Biologia = Brazilian Journal of Biology, vol. 63, no 1, p. 129-132.

VANZOLINI, PE., RAMOS-COSTA, AMM. and VITT, LJ., 1980. Répteis das caatingas. Rio de Janeiro: Academia Brasileira de Ciências. 161p.

VICENTE, JJ., RODRIGUES, HO., GOMES, DC. and PINTO, RM., 1993. Nematóides do Brasil, parte III: nematóides de répteis. Revista Brasileira de Zoologia, vol. 10, no. 1, p. 19-168.

VITT, LJ., 1995. The ecology of tropical lizards in the caatinga of northeastern Brasil. Occasional Papers of the Oklahoma Museum of Natural History, vol. 1, p. 1-29.

VRCIBRADIC, D., ROCHA, CFD., RIBAS, SC. and VICENTE, JJ., 1999. Nematodes infecting the skink Mabuya frenata in Valinhos, São Paulo State, Southeastern Brazil. AmphibiaReptilia, vol. 20, no. 3, p. 333-339.

VRCIBRADIC, D., CUNHA-BARROS, M., VICENTE JJ., GALDINO, CAB., HATANO, FH., VAN SLUYS, M. and ROCHA, CFD., 2000. Nematode infection patterns in four sympatric lizards from a restinga habitat (Jurubatiba) in Rio de Janeiro state, southeastern Brazil. Amphibia-Reptilia, vol. 21, no. 3, p. 307-316.

VRCIBRADIC, D., ROCHA, CFD., BURSEY, CD. and VICENTE JJ., 2002a. Helminths infecting Mabuya agilis (Lacertilia, Scincidae) in a 'restinga' habitat (Grumari) of Rio de Janeiro, Brazil. Amphibia-Reptilia, vol. 23, no. 1, p. 109-114.

2002b. Helminth communities of two sympatric skinks (Mabuya agilis and Mabuya macrorhyncha) from two 'restinga' habitats in southeastern Brazil. Journal of Helminthology, vol. 76, no. 4, p. 355-361.

VRCIBRADIC, D., VICENTE, JJ. and BURSEY, CD., 2007. Helminths infecting the lizard Enyalius bilineatus (Iguanidae: Leisosaurinae) from an Atlantic Rainforest area in Espírito Santo state, southeastern Brazil. Amphibia-Reptilia, vol. 28, no. 1, p.166-169. 